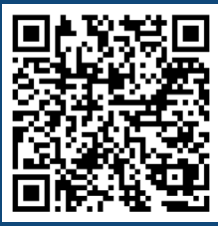

Keywords:

Natural forest

Pinus ponderosa

Planted forest

Rocky outcrop

Wetland

Historic:

Received $21 / 05 / 2019$

Accepted 16/09/2019

Correspondence: dezzotti@infovia.com.ar
Alejandro Dezzottila+, Ariel Mortorolb, Andrea Medina ${ }^{\mathrm{lc}}$, Renato Sbrancial ${ }^{\mathrm{ld}}$, Hernán Attis Beltrán ${ }^{\text {ld }}$

\section{PLANT RICHNESS AND LIFE FORM DIVERSITY ALONG VEGETATION AND FOREST USE GRADIENTS IN NORTHWESTERN PATAGONIA OF ARGENTINA}

DEZZOTTI, A.; MORTORO, A.; MEDINA, A.; SBRANCIA, R.; BELTRAN, H. A. Plant richness and life form diversity along vegetation and forest use gradients in northwestern patagonia of Argentina. CERNE, v. 25, n. 3, p.30I-3I3, 2019.

\section{HIGHLIGHTS}

Dense stands exhibited reduced solar radiation and plant diversity in the understory, and water content in the topsoil.

Rocky outcrops showed a restricted size but a high diversity of native plants.

Fenced vegetation units have a higher plant cover and diversity than their unfenced counterparts.

Compatibility between plant diversity and timber production requires fencing and an ample tree spacing.

\section{ABSTRACT}

The imbalace between the increase in the demand and the decrease in the supply of products from natural forests, partly explains the on-going development of exotic tree plantations. In northwestern Patagonia of Argentina, Pinus ponderosa (Pinaceae) afforestation plays a key role in ameliorate degraded soils, but may also reduce biodiversity. The ecological sustainability of this activity was assessed in Aguas Frías $\left(38^{\circ} 46^{\prime} \mathrm{W}, 70^{\circ} 54^{\prime}\right.$ S) and Litrán $\left(38^{\circ} 54^{\prime} \mathrm{W}, 7 \mathrm{I}^{\circ} \mathrm{OI}\right.$ ' S) forest stations, where species richness and life form diversity of plants were compared in vegetation units, fenced and unfenced against livestock. Eleven vegetation units were identified, including natural herbaceous-shrubby steppes, xerophilous and hygrophilous meadows, pure and mixed forests of Nothofagus pumilio (Nothofagaceae) and Araucaria araucana (Araucariaceae), and P. ponderosa planted forests of dissimilar canopy cover. Xerophilous meadows on rocky outcrops held I/3 of total richness in an extremely restricted area. Hygrophilous meadows exhibited the largest number of families and native and exotic species, and lower diversity of life forms. Dense pine stands exhibited low values of light in the undergrowth, water in the topsoil, cover of undergrowth plants, frequency of hemicriptophytes and richness and diversity of life forms. As canopy cover decreased, values for these indicators resembled those of the steppe of reference. Within a plantation, greater compatibility between conservation of diversity and wood production requires maintenance of fencing, reduced tree spacing over long rotations and the development of buffer zones and biological corridors. Although such a project may represent a decline in productivity, it will promote enhanced ecosystem and aesthetic values, increasing the likelihood of further economic support from society. 


\section{INTRODUCTION}

Over the last 50 years natural forests of native species have been severely transformed by anthropogenic activities (Lindquist et al., 20l3). At the same time, the need for goods and services from these ecosystems continues to increase (FAO, 20I8). The current imbalance between the supply and demand of forest resources partly explains the growing establishment of tree plantations through afforestation and reforestation programmes (Overbeek et al., 20I2). The environmental sustainability of these plantations generates conflicting views, considering them everything from valuable habitats for indigenous biota (Carnus et al., 2006), to "green deserts" (Overbeek et al., 20I2). Biological diversity constitutes an indicator of ecosystem functioning and resilience, and therefore makes it possible to measure the relationship between environment and human activity (Haines-Young, 2009).

The interacting factors that control the species diversity of plants operate along gradients, and are linked to the local and regional gene pool and performance of populations, environmental conditions, spatial heterogeneity, and stress and disturbance (Drakare et al., 2006). In particular, the effect of plantations on diversity depends on the previous land use, the structure and conservation of original vegetation, the origin, composition, canopy cover and physiognomy of the trees, and the silvicultural prescriptions. Intensive silviculture tends to be detrimental to diversity, since it reduces the availability of essential aerial and subterranean resources, and also precludes the existence of stands in advanced stages of development, reducing the abundance of snags and large trees and encouraging the dominance of one or few species (Bremer and Farley, 2010).

Functional diversity is the constituent of plant diversity that measures the value of physical, biochemical, phenological or behavioural traits, observably or operationally defined, which potentially affect organism performance and ecosystem processes (Devictor et al., 20I0). Weiher (20I I) proposed that species coexistence depends on high degrees of trait dispersion, implying that community is structured by competition, and low levels of stress. In contrast, Kleidon et al. (2009) claimed that coexisting species tend to be phenotypically similar because habitat filters certain traits. Although functional diversity can predict productivity, stability and resource dynamics more accurately than taxonomic diversity, its measurement is complex due to the incomplete knowledge of exactly which species characteristics affect community functioning (Tilman, 200I). Therefore, patterns might be more easily interpreted when considering both taxonomic and functional diversity (Cadotte et al., 20I I).

The life form of a plant represents plant morphology as an adjustment to ecological conditions. Individuals with a particular life form are expected to exhibit similar responses to environmental variation and to exert analogous effects on ecosystem processes (Tilman, 200I). Life form classification is based on the position and protection of renewal buds (Raunkiær, 1934). The life form structure of a community can be represented by both floristic and vegetational biological spectra. The floristic spectrum represents the relative number of species with each life form, and therefore every species makes the same contribution to the community. The vegetational spectrum considers species abundance, and consequently each class is weighted by frequency; it takes into account the occurrence of vegetation rather than flora and is more readily comparable to spectra from other sites (Batalha and Martins, 2004).

In northwestern Patagonia of Argentina, afforestation was initiated in the 1970s in non-irrigated areas within the forest - steppe transition of the Andes foothills, and comprises around 100000 ha. Pinus ponderosa ((Dougl.) Laws, Pinaceae) occupies $95 \%$ of this area due to its satisfactory growth under the prevailing dry, windy summer conditions and cold winters (MAGyP, 20I4). Pines were mostly planted in natural pastures that were severely degraded, due mainly to overgrazing (MAGyP, 20I4). These plantations contribute to reducing soil erosion, conserving fragile ecosystems and capturing $\mathrm{CO}_{2}$ (Frugoni et al., 2016; Laclau et al., 2017). However, they can invade surrounding communities (Simberloff et al., 20I0) and increase the fire hazard (Loguercio et al., $20 \mathrm{II})$. The effect of these plantations on species richness has been evaluated in insects (Corley et al., 2006), birds (Lantschner et al., 2008) and mammals (Lantschner et al., 20II, 20I2). Plants, with their enormous potential for regulation of ecosystem structure and function, have received little attention.

The overall aim of our study was to assess the ecological sustainability of afforestation with $P$. ponderosa at management unit level, within a single geomorphological zone and under different silvicultural regimes. In particular, we investigated the baseline of species richness and life form diversity for vascular plants in contrasting vegetation units. We described how diversity diverged from open units, dominated by herbs and shrubs in steppes and meadows, to closed units occupied by trees in natural and planted forests. We analysed the relationship between life form assemblage and the structural heterogeneity of pine stands, particularly in relation to the steppe as the ecosystem 
of reference. The effect of fencing was also evaluated, in terms of protection against consumption and trampling of livestock, both of which affect plant diversity. A species - assemblage study across a range of managed and unmanaged vegetation units, provides a means of exploring the value of plantations for harbouring wild plants, as a long term diversity conservation strategy complementary to that of the natural areas afforded by set-asides alone (Chown and McGeoch, 20I I).

We hypothesized that although richness and life form diversity vary greatly between units, plantations show lower values than natural forests, regardless of their composition and structure. Within P. ponderosa stands, variability among structural types is mostly related to population pattern and competition. However, open $P$. ponderosa stand diversity approaches that of the steppe, due not only to greater heterogeneity, related to plant size, life form and habitat, but also a larger quantity of resources for understory plants, related to light and water. The silvicultural practice of fencing improves the conservation status of communities, which is evidenced in higher diversity values. Afforestation can be compatible with both timber production and provision of food, habitat and connectivity for wild flora and fauna. Such a strategy involves trade-offs that are plausible if plantation ecology is taken into account on temporal and spatial scales (CBD, 2019).

\section{MATERIALS AND METHODS}

\section{Study area}

The study area comprised the forest stations Aguas Frías (3846' W, $70^{\circ} 54^{\prime} \mathrm{S}, 1590$ m a.s.l., 456 ha) and Litrán (38 $54^{\prime} \mathrm{W}, 7 \mathrm{I}^{\circ} \mathrm{O} \mathrm{I}^{\prime} \mathrm{S}, 1400 \mathrm{~m}$ a.s.l., I $\left.310 \mathrm{ha}\right)$. Climate is warm-summer Mediterranean (Csb) (Peel et al., 2007; AIC, 20 I5) (Figure I). Geomorphology burden of Holocene tephra from the active volcanoes of the Andes. These rocks constitute the parent material of the well-developed and dominant allophanic Udivitrand and EndoaquandAndisols(Frugoni etal., 2016). The vegetation represents a transition between the semiarid Patagonian and the humid Subantarctic ecoregions, and steppe plants predominate in the bottomlands on zonal soils (Oyarzábal et al., 2018). Nothofagus (Nothofagaceae) forests grow at mid elevation on slopes of different exposures in the western part of the study area, and open woodlands of varying composition lie to the east, surrounded by the steppe (Frugoni et al., 2016). This area has traditionally been used as a migration route for the nomadic ranching of goats and sheep, as they went from bottom valleys in winter to higher elevations in summer. Here, higher pastures are located from I,400 to I,700 m a.s.l., approximately. Plants are intensely overgrazed and burnt

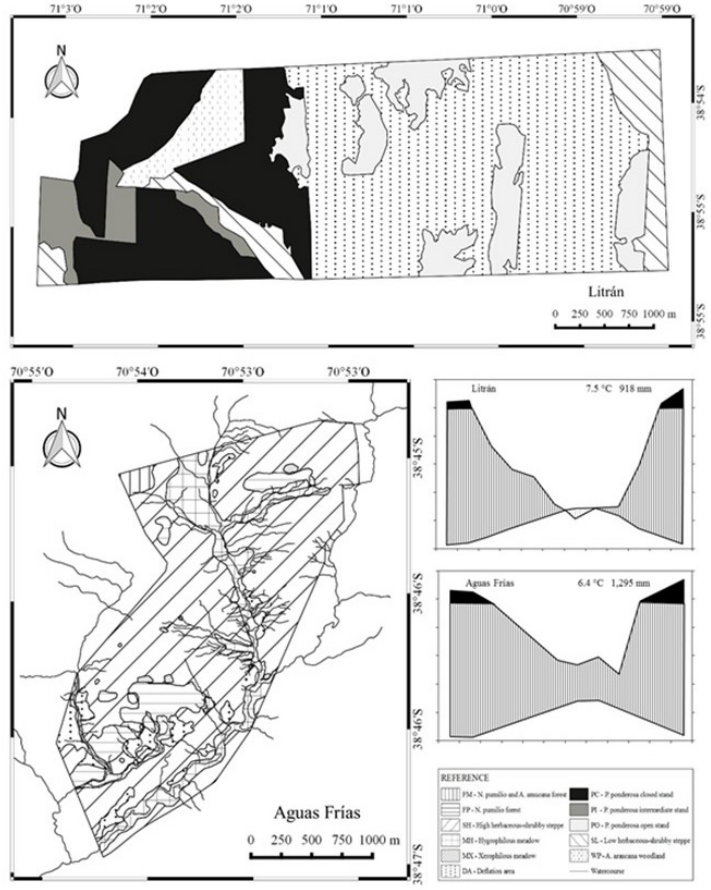

FIGURE I Vegetation units and climatic diagrams of Aguas Frías and Litrán..

as a consequence of this practice (Frugoni et al., 2016). Pines were planted in the deep, well-drained soils of the steppe between 1991 and 1995 in Litrán, and in 2010 in Aguas Frías. A fence against livestock circumscribed the forest stations, and a fire control system was implemented.

Vegetation units, soil features and solar radiation

Vegetation units were identified on an Aster satellite image (resolution $15 \mathrm{~m}$, Gauss Krüger coordinates band I, ellipsoid WGS 1984), using vegetation composition and structure as guiding criteria; the resulting cartography was verified in the field. In each unit, 10 sampling sites were equidistantly located within the boundaries of forest stations (fenced condition). In addition, 10 sampling sites were selected near Aguas Frías, in units covered by natural forest and steppe (unfenced condition). In each sampling site, geographical position (GPS), altitude (altimeter), slope (clinometer, metric tape) and exposure (compass) was recorded. Soil bulk density (SBD) was estimated during the dry season through the cylinder method, by randomly removing three samples of the soil A-horizon, which was then weighed in the laboratory (metal cylinder with three mobile rings, scale precision $0.001 \mathrm{~g}, \mathrm{n}=3$ ) (SAMLA, 2004). During the dry season, soil moisture (SM) was estimated through the gravimetric method, by collecting soil samples of the A-horizon from each unit, which were hermetically stored and weighed in the laboratory, 
then dried for $24 \mathrm{~h}$ at $90^{\circ} \mathrm{C}$ and weighed again (oven, scale precision $0.001 \mathrm{~g}, \mathrm{n}=3$ ) (SAMLA, 2004). Photosynthetically active radiation (PAR) was measured at $0.2 \mathrm{~m}$ aboveground, as relative intensity in comparison with an adjacent fully open area, using a light receiver LI250 and a quantum sensor LI-I90SA (LI COR, Inc., $n=$ 10) (Mottus et al., 20I I).

\section{Vegetation structure and diversity}

In each unit covered by pure and mixed natural forests, a $1000 \mathrm{~m}^{2}$ - permanent sampling plot was chosen at random, and all living trees, including adults (diameter at base height $\left.d_{b} \geq 0.1 \mathrm{~m}\right)$ and saplings $\left(d_{b}<0.1 \mathrm{~m}\right.$, height $h>0.1 \mathrm{~m}$ ), were measured for $d_{b}$ (diameter tape, calliper) and $h$ (hypsometer, metric tape). Seedlings $\left(d_{b}<\right.$ $0.1 \mathrm{~m}, h \leq 0.1 \mathrm{~m}$ ) were counted in $200.5 \mathrm{~m}^{2}$ - square plots systematically located within the main plot. Pinus ponderosa stands were categorized as open $\left(<15 \mathrm{~m}^{2} / \mathrm{ha}\right.$ basal area, BA), intermediate (I5 - $30 \mathrm{~m}^{2} / \mathrm{ha}$ ), and closed (> $30 \mathrm{~m}^{2} /$ ha) using a forest inventory classification (CFI, 2009). In each structural category, a $400 \mathrm{~m}^{2}$ - plot was randomly installed and trees were measured for $d_{b}$. Mean distance between pines $(d, m)$ was estimated using tree density $\left(D\right.$, ind/ha), according to $d=(10000 \square D)^{0.5}$. Four trees with the thickest and one with the thinnest trunk were measured for length of the five internodes above $h$ $=1.3 \mathrm{~m}\left(I_{5}, \mathrm{~m}\right.$, metric tape). In each stand, site index for a reference age of 20 years $\left(\mathrm{SI}_{20}, \mathrm{~m}\right)$ was calculated as $\mathrm{SI}_{20}=$ $4.37+14.86 I_{5} / 5$ (Andenmatten and Letorneau, 2003).

From the centre of each sampling site, four 10 $\mathrm{m}$ - transects were installed following the N, S, E and W directions. On each transect 10 sampling points were located I m apart to determine the frequency of bare soil (BS), crown cover of adult trees (CC), total $\left(S_{t}\right)$ and mean $(\square)$ species richness, life form richness (LFR) and diversity (LFD), and floristic (FBS) and vegetational (VBS) spectra of vascular plants, based on frequency data and the point-intercept method (Kent, 20II). Plants were classified according to species, origin (native, exotic), life cycle (perennial, biannual, annual) (IBD, 2019) and life form (Raunkiær, 1934; Bertolami et al., 2008). All variables expressed as percentages were normalized through transformation into angular values prior to determining the effects of ANOVA. A Chi-square test was applied to verify whether spectra were significantly different from those expected under a random distribution of life forms. LFR and LFD were calculated through the FD package (Villéger et al., 2008; Laliberté et al., 2019). Comparisons of $S_{t}, \hat{S}$, LFR and LFD between units and fencing condition were performed with univariate and bivariate statistical methods.

\section{RESULTS}

Vegetation units, soil features and solar radiation

In the study area, II vegetation units were identified, covered by steppes, meadows, and natural and planted pure and mixed forests and woodlands. In Aguas Frías, units were categorized as "natural" because of the evolutive origin of the dominant plants. These were the high herbaceous-shrubby steppe (SH, 69.4\% of the station area), the hygrophilous ( $\mathrm{MH}, 15.1 \%)$ and xerophilous meadows (MX, I.I\%), the deflation area of pyroclastic material (DA, 5.8\%), the pure forest of deciduous broadleaved Nothofagus pumilio ((Poepp. \& Endl.) Krasser, Nothofagaceae) (FP, 7.6\%) and mixed forest of $N$. pumilio and the evergreen conifer Araucaria araucana ((Molina) K. Koch, Araucariaceae) (FM, I.0\%). In Litrán, the natural units were DA (45.1\%), the low herbaceous-shrubby steppe (SL, 8.8\%) and the $A$. araucana woodland with dispersed Nothofagus antarctica ((G. Forst.) Oerst.) deciduous trees (WP, 4.8\%). The "artificial" units with planted dominant species were the P. ponderosa open (PO, 12.8\%), intermediate (PI, 5.1\%) and closed forest (PC, 23.5\%) (Figure I).

Mean SBD was $0.66 \mathrm{~g} / \mathrm{cm}^{3}$ (SE $\left.=0.05\right)$; means did not significantly differ between units (Table I, Figure 2). Mean $S M$ was $24.7 \%$ ( $S E=5.8$ ), with a minimum value in $\mathrm{PC}(9.6 \%, \mathrm{SE}=0.9)$ and a maximum in unfenced high steppe $\mathrm{SH}_{\mathrm{u}}(78.8 \%$, $\mathrm{SE}=2.1)$; means significantly differed between units: PC $(9.6 \%$, SE $=$

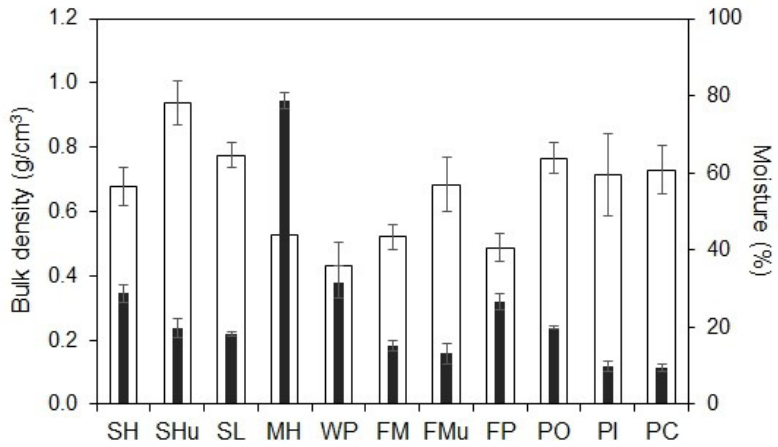

FIGURE 2 Bulk density (empty bar) and moisture (filled bar) of soil A-horizon in Aguas Frías and Litrán. Vertical bars indicate the standard error of the mean. Mean soil moisture differs among units (LSD test, $\mathrm{p}<0.05, \mathrm{n}=$ 3). $\mathrm{SH}$ : high herbaceous-shrubby steppe, fenced and (u) unfenced, SL: low herbaceous-shrubby steppe, $\mathrm{MH}$ : hygrophilous meadow, WP: A. araucana woodland, FM: N. pumilio and A. araucana forest fenced and (u) unfenced, FP: $N$. pumilio forest, PO: P. ponderosa open forest, PI: P. ponderosa intermediate forest, and PC: $P$. ponderosa closed forest.. 
$0.9)$ and $\mathrm{PI}(9.9 \%, \mathrm{SE}=1.4)$ showed a lower value than PO $(19.9 \%$, SE $=0.4)$. Mean SM did not differ between FM (I3.2\%, SE = 2.6) and $\mathrm{FM}_{\mathrm{u}}(\mathrm{I} 5.2 \%$, SE = I.2), whereas it did vary between $\mathrm{SH}(28.7 \%, \mathrm{SE}=2.2)$ and $\mathrm{SH}_{u}(19.8 \%, \mathrm{SE}=2.5)$ (Table I, Figure 2). In forest units, $S M$ decreased as CC increased (ANOVA, $F=5.72$, $\mathrm{p}=0.042, \mathrm{n}=7$ ) (Figure 3). Mean BS was $44.0 \%(\mathrm{SE}=$ 2.6); means significantly differed between units (Table I): PC (89.3\%), PI (85.4\%), and DA (83.6\%) showed the greatest values, whereas $\mathrm{MH}(5.9 \%)$ and $\mathrm{MX}(17.5 \%)$ showed the lowest values. Mean BS was statistically lower in fenced than in unfenced condition (SH, 27.1\%, $\mathrm{SE}=4.4 ; \mathrm{SH}_{\mathrm{u}}, 40.2 \%$, SE = 5.7; FM, 34. $1 \%$, SE = 9.2; $\left.\mathrm{FM}_{u}, 5 \mathrm{I} .4 \%, \mathrm{SE}=3.5\right)(t$ test, $\mathrm{p}<0.05)$. BS in $\mathrm{PI}(83.6 \%$, $\mathrm{SE}=3.8)$ and $\mathrm{PC}(89.3 \%, \mathrm{SE}=3.6)$ was significantly lower than in $\mathrm{PO}(28.2 \%, \mathrm{SE}=3.7)$. BS showed a direct relationship with $C C$ in pine stands (ANOVA, $F=93.01$, $p<0.001, n=30$ ), and an inverse relationship with $S M$ in

TABLE I Analysis of variance for physical and biological variables of the vegetation units of Aguas Frías and Litrán. The degrees of freedom (df), F-quotient and sample size (n) are shown, $(*)$ denotes significant differences of means between units, based on LSD test $(p<0.05)$, ns: non-significant. (I) Based on hemicryptophytes..

\begin{tabular}{ccccc}
\hline Variable & $\mathrm{df}$ & $\mathrm{F}$ & $\mathrm{p}$ & $\mathrm{n}$ \\
\hline Soil bulk density (g/cm3) & 44 & 2.0 & $0.063 \mathrm{~ns}$ & 3 \\
Soil moisture (\%) & 41 & 47.4 & $<0.00 I^{*}$ & 3 \\
Bare soil (\%) & 129 & 38.2 & $<0.00 I^{*}$ & 10 \\
Light intensity bellow canopy (\%) & 69 & 2.7 & $0.019^{*}$ & 10 \\
Species richness & 129 & 17.8 & $<0.00 I^{*}$ & 10 \\
Plant families (number) & 129 & 9.8 & $<0.00 I^{*}$ & 10 \\
Native species (\%) & 129 & 59.4 & $<0.00 I^{*}$ & 10 \\
Perennial species (\%) & 129 & 9.7 & $<0.00 I^{*}$ & 10 \\
Annual species (\%) & 129 & 5.7 & $<0.00 I^{*}$ & 10 \\
Tree species (\%) & 129 & 6.9 & $<0.00 I^{*}$ & 10 \\
Shrub species (\%) & 129 & 41.3 & $<0.00 I^{*}$ & 10 \\
Herb species (\%) & 129 & 62.5 & $<0.00 I^{*}$ & 10 \\
Floristic spectrum(I) & 129 & 13.6 & $<0.00 I^{*}$ & 10 \\
Vegetational spectrum(I) & 129 & 38.0 & $<0.00 I^{*}$ & 10 \\
Life form richness & 129 & 3.4 & $<0.00 I^{*}$ & 10 \\
Life form diversity & 129 & 12.1 & $<0.00 I^{*}$ & 10 \\
\hline
\end{tabular}

all forest units (ANOVA, $\mathrm{F}=157.46, \mathrm{p}<0.00 \mathrm{I}, \mathrm{n}=\mathrm{I}$ I) (Figure 4). Mean PAR was $2.0 \%$ in PC (SE $=0.5), 13.0 \%$ in $\mathrm{FM}(\mathrm{SE}=9.7), 13.9 \%$ in $\mathrm{FM}_{\mathrm{u}}$ (SE $\left.=9.4\right), 16.3 \%$ in PI (SE = $7.3), 24.5 \%$ in WP (SE $=8.3$ ), $31.9 \%$ in FP (SE = 7.9) and $42.0 \%$ in $\mathrm{PO}$ (SE = 3.9). These values were significantly different from each other, but FM and $\mathrm{FM}_{\mathrm{u}}$ showed the same statistical mean ( $t$ test, $F=0.00, p=0.946$ ) (Table I). In forest units, PAR decreased as CC increased (ANOVA, $\mathrm{F}=44.49, \mathrm{p}<0.00 \mathrm{I}, \mathrm{n}=7$ ) (Figure 3).

\section{Forest structure and plant richness}

In woodland and forests, $D$ varied from $95 \mathrm{ind} / \mathrm{ha}$ (WP) to $775 \mathrm{ind} / \mathrm{ha}$ (PC), and $B A$ from $11.1 \mathrm{~m}^{2} / \mathrm{ha}$ (PO) to $97.7 \mathrm{~m}^{2} / \mathrm{ha}$ (FM). Pinus

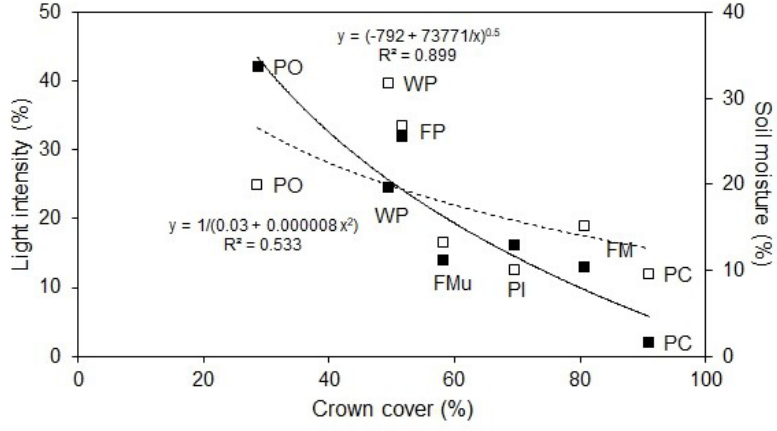

FIGURE 3 Light intensity (black square, continuous line) and soil moisture (white square, dashed line) related to crown cover in Aguas Frías and Litrán. The parameters of the regression function and the coefficient of determination (R2) are indicated (ANOVA, $\mathrm{P}<$ $0.05, n=7)$. WP: A. araucana woodland, FM: N. pumilio and $A$. araucana forest fenced and (u) unfenced, FP: N. pumilio forest, PO: P. ponderosa open forest, PI: P. ponderosa intermediate forest and PC: P. ponderosa closed forest.

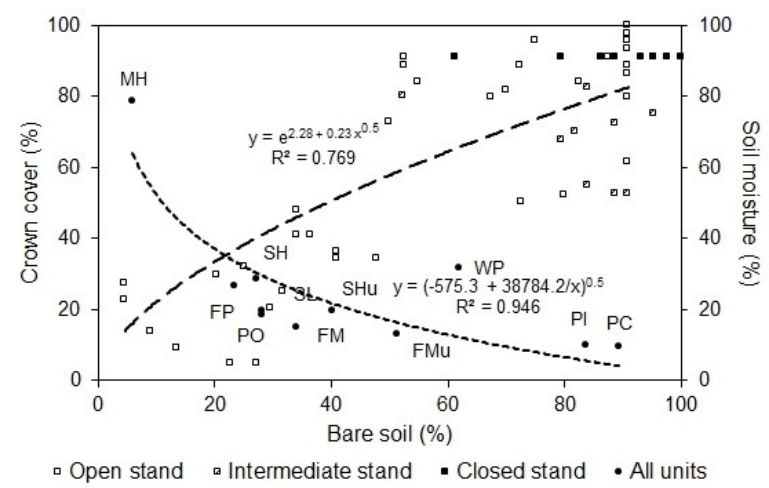

FIGURE 4 Crown cover (continuous line, primary $y$-axis) and soil moisture (dashed line, secondary $y$-axis) related to bare soil in the P. ponderosa stands (ANOVA, $F=93.01, P$ $<0.000, \mathrm{n}=30$ ) and in all vegetation units (ANOVA, $\mathrm{F}=157.46, \mathrm{p}<0.000, \mathrm{n}=\mathrm{I} \mathrm{I}$ ) of Aguas Frías and Litrán. The parameters of the regression function and the coefficient of determination (R2) are indicated. $\mathrm{SH}$ : high herbaceous-shrubby steppe, fenced and (u) unfenced, SL: low herbaceous-shrubby steppe, $\mathrm{MH}$ : hygrophilous meadow, WP: A. araucana woodland, FM: N. pumilio and A. araucana forest fenced and (u) unfenced, FP: N. pumilio forest, PO: P. ponderosa open forest, $\mathrm{Pl}$ : $\mathrm{P}$. ponderosa intermediate forest and PC: P. ponderosa closed forest.

ponderosa stands differed in mean $d_{b}, D, B A$ and $C C$; PO presented the lowest and PC the largest values. The potential for growth of the pine trees was equivalent, as stands belonged to the same site index class (Table 2). The diameter-class frequency distribution of natural forests differed between species. Araucaria araucana approached an irregular, multi-modal size distribution in which for mixed forest, small individuals $\left(d_{b}=10\right.$ - 
TABLE 2 Structure of forests and woodlands in Aguas Frías and Litrán. nd: no data.

\begin{tabular}{|c|c|c|c|c|c|c|c|}
\hline \multirow{2}{*}{\multicolumn{2}{|c|}{ Variable }} & \multicolumn{2}{|c|}{ N. pumilio and $A$. araucana forest } & \multirow{2}{*}{$\begin{array}{l}\text { A. araucana } \\
\text { woodland }\end{array}$} & \multicolumn{3}{|c|}{ P. ponderosa plantation } \\
\hline & & Mixed & Pure & & Open & Intermediate & Closed \\
\hline \multirow{3}{*}{ Density (ind/ha) } & Adult & 235 & 128 & 95 & 350 & 400 & 775 \\
\hline & Sapling & 275 & 2105 & 10 & - & - & - \\
\hline & Seedling & 1000 & 148000 & - & - & - & - \\
\hline \multirow{3}{*}{\multicolumn{2}{|c|}{$\begin{array}{l}\text { Distance }(\mathrm{m}) \\
\text { Diameter }(\mathrm{cm}) \\
\text { Height }(\mathrm{m})\end{array}$}} & nd & nd & nd & 5.3 & 5.0 & 3.6 \\
\hline & & 55.6 & 59.3 & 59.5 & 19.7 & 27.9 & 27.0 \\
\hline & & 13.1 & 13.0 & II.I & 6.9 & 12.1 & 12.3 \\
\hline \multirow{2}{*}{\multicolumn{2}{|c|}{ Site index $(m)$}} & nd & nd & nd & 12.6 & 13.2 & 14.6 \\
\hline & & 97.7 & 27.2 & 35.1 & 11.1 & 24.6 & 45.3 \\
\hline \multicolumn{2}{|c|}{$\begin{array}{l}\text { Basal area }(\mathrm{m} 2 / \mathrm{ha}) \\
\text { Crown cover }(\%)\end{array}$} & 80.7 & 51.6 & 47.1 & 28.6 & 69.5 & 90.9 \\
\hline
\end{tabular}

$39.9 \mathrm{~cm}$ ) formed the largest category with $69.2 \%$ of total trees, and for the woodland, small $\left(d_{b}=10-19.9 \mathrm{~cm}\right)$ and intermediate $\left(d_{b}=60-69.9 \mathrm{~cm}\right)$ specimens formed the largest category, accounting for $68.4 \%$ of total trees. In contrast, $N$. pumilio approached a regular, normal distribution in which medium-sized trees comprised the most abundant class (Figure 5).

In the study area 154 species of plants were identified, Carex (Cyperaceae, 9 species), Senecio (Asteraceae, 8) and Festuca (Poaceae, 5) being the most diverse genera. $S_{t}$ ranged from $16(\mathrm{PC}$ and $\mathrm{PI})$ to $68(\mathrm{MH}) . \mathrm{S}_{t}$ was similar in $\mathrm{FM}(24)$ and $\mathrm{FM}_{u}(23)$, whereas it differed in $\mathrm{SH}(47)$ and $\mathrm{SH}_{\mathrm{u}}$ (24) (Table 3). $\hat{S}$ statistically differed between units; the smallest value was found in PC (3.6) and the largest in $\mathrm{MH}$ (17.I). $\hat{S}$ was low and statistically similar in PC (3.6) and PI (4.9), but differed from PO (13.6). $\hat{S}$ did not differ between fenced and unfenced conditions; $\mathrm{SH}, \hat{\mathrm{S}}=10.7$ and $\mathrm{SH}_{\mathrm{u}}$,
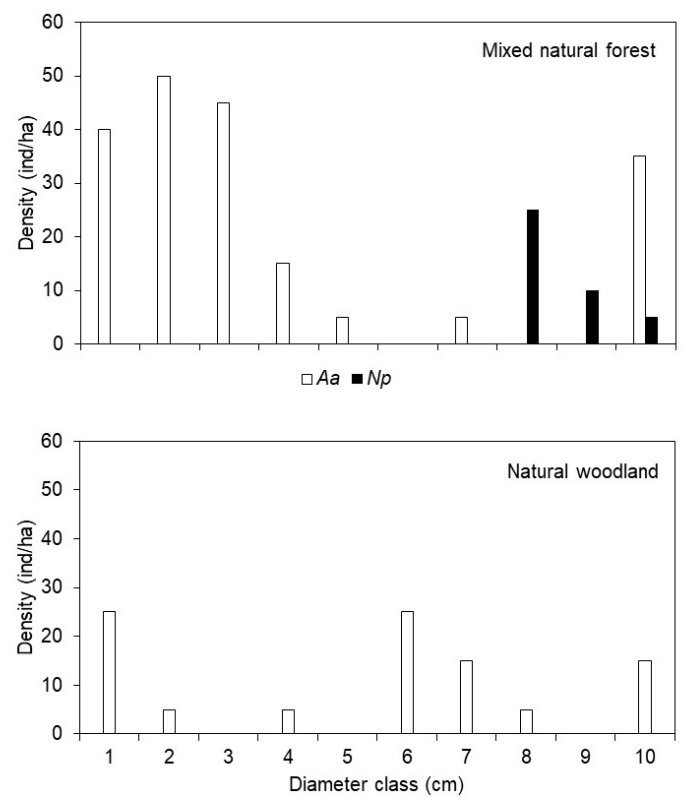

$\square A a$

$\hat{S}=8.5 ; F M, \hat{S}=7.5$ and $F M_{u}, \hat{S}=8.6$ ( $t$ test, $p \geq$ 0.05) (Tables I and 3). Plants belonged to 49 families, Asteraceae (27 species) and Poaceae (24) being the most diverse. Number of families statistically differed between units (Table I); the lowest value was in PI (total 9, mean $3.2, \mathrm{SE}=0.5)$ and the largest in $\mathrm{MH}(23,8.9, \mathrm{SE}=0.7)$. $\mathrm{PI}$ and $\mathrm{PC}(3.4, \mathrm{SE}=2.5)$ showed very low mean values, differing statistically from $\mathrm{PO}(8.4, \mathrm{SE}=0.3)$ (LSD test, $\mathrm{p}<0.05$ ). Although mean number of families tended to be higher in fenced than in unfenced condition, the differences were not significant ( $t$ test, $p \geq 0.05$ ). As a rule, $B S$ and $S_{t}$ showed an inverse relationship. In pine stands, there was a strong linear relation between these variables (ANOVA, $\mathrm{p}<0.00 \mathrm{I}, \mathrm{n}=30$ ), whereas in natural units the function was polynomic, with lower goodness of fit (ANOVA, $\mathrm{p}<0.00 \mathrm{I}, \mathrm{n}=100$ ); in both data sets, $S_{t}$ variability was much higher below $60 \%$ of BS (Figure 6).
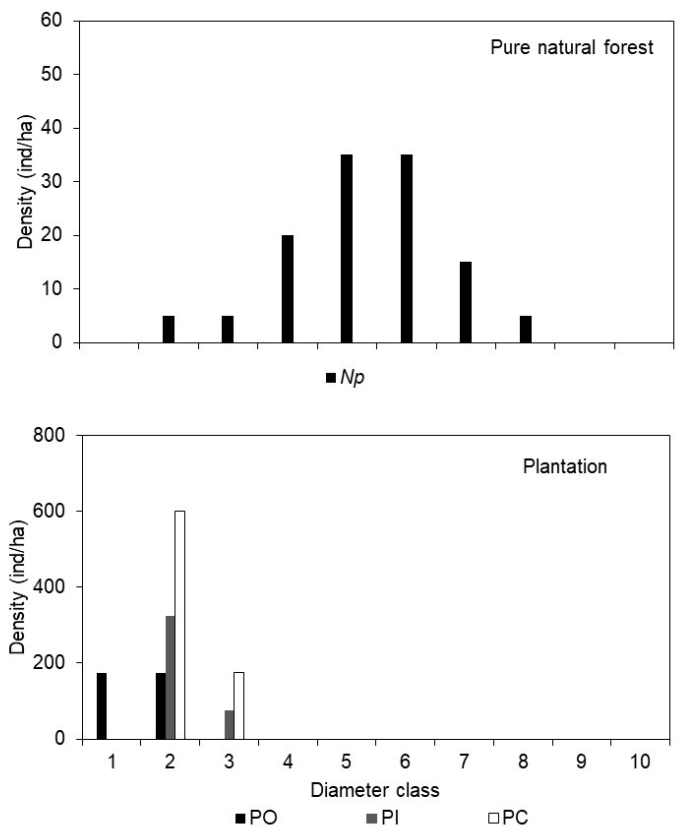

Figure 5. Diameter-class frequency distribution (1: $10-19.9,2: 20-29.9, \ldots, 10:>100 \mathrm{~cm}$ ) of N. pumilio(black bar) and A. araucana (white bar) (above), and P. ponderosa (bellow) forests in Aguas Frias and Litrán.

FIGURE 5 Diameter-class frequency distribution (I: 10 - 19.9, 2: $20-29.9, \ldots, 10:>100 \mathrm{~cm}$ ) of N. pumilio (black bar) and A. araucana (white bar) (above), and P. ponderosa (bellow) forests in Aguas Frías and Litrán. 
TABLE 3 Species richness and frequency (\%) of native, perennial, annual, tree, shrub and herb species, difference (as the module) between the floristic (FBS) and vegetational (VBS) spectra and life form richness (LFR) and diversity (LFD) in the vegetation units of Aguas Frías and Litrán. Mean ( $\overline{\mathrm{X}}$ ) and standard error (SE) are shown. SH: high herbaceous-shrubby steppe, fenced and (u) unfenced, SL: low herbaceous-shrubby steppe, $M H$ : hygrophilous meadow, $M X$ : xerophilous meadow, DA: deflation area, WP: A. araucana woodland, FM: N. pumilio and A. araucana forest fenced and (u) unfenced, FP: N. pumilio forest, PO: P. ponderosa open forest, PI: P. ponderosa intermediate forest and PC: P. ponderosa closed forest.

\begin{tabular}{|c|c|c|c|c|c|c|c|c|c|c|c|c|c|c|c|c|c|c|c|c|c|}
\hline \multirow{2}{*}{ Unit } & \multicolumn{3}{|c|}{ Richness } & \multicolumn{2}{|c|}{ Native } & \multicolumn{2}{|c|}{ Perennial } & \multicolumn{2}{|c|}{ Annual } & \multicolumn{2}{|c|}{ Tree } & \multicolumn{2}{|c|}{ Shrub } & \multicolumn{2}{|c|}{ Herb } & \multicolumn{2}{|c|}{ FBS-VBS } & \multicolumn{2}{|c|}{ LFR } & \multicolumn{2}{|c|}{ LFD } \\
\hline & Total & $\overline{\mathrm{x}}$ & SE & $\overline{\mathrm{x}}$ & SE & $\overline{\mathrm{x}}$ & SE & $\overline{\mathrm{x}}$ & SE & $\overline{\mathrm{x}}$ & SE & $\overline{\mathrm{x}}$ & SE & $\overline{\mathrm{x}}$ & SE & $\overline{\mathrm{x}}$ & SE & $\overline{\mathrm{x}}$ & SE & $\overline{\mathrm{x}}$ & SE \\
\hline $\mathrm{SH}$ & 47 & 10.7 & 1.4 & 90.6 & 5.1 & 98.4 & 0.8 & 1.6 & 0.8 & 1.4 & 1.0 & 1.4 & 1.0 & 77.6 & 4.8 & 4.9 & 1.2 & 3.7 & 0.3 & 0.23 & 0.03 \\
\hline $\mathrm{SHu}$ & 24 & 8.5 & 0.7 & 97.2 & 1.0 & 99.3 & 0.8 & 0.8 & 0.8 & 0.7 & 0.3 & 0.7 & 0.3 & 81.4 & 1.0 & 2.5 & 1.5 & 2.8 & 0.3 & 0.21 & 0.01 \\
\hline SL & 38 & 14.8 & 1.0 & 82.2 & 0.9 & 99.2 & 0.5 & 0.7 & 0.5 & 1.3 & 0.7 & 1.3 & 0.7 & 94.2 & 1.5 & 3.5 & 2.0 & 2.6 & 0.3 & 0.08 & 0.02 \\
\hline $\mathrm{MH}$ & 68 & 17.1 & 1.2 & 82.0 & 5.4 & 92.9 & 1.6 & 1.9 & 1.5 & 0.5 & 0.2 & 0.5 & 0.2 & 89.2 & I. & 1.2 & 0.6 & 3.3 & 0.3 & 0.15 & 0.02 \\
\hline$M X$ & 50 & 12.1 & 0.9 & 98.5 & 0.8 & 100 & 0.0 & 0.0 & 0.0 & 10.5 & 3.2 & 10.5 & 3.2 & 55.7 & 4. & 1.7 & 0.8 & 3.0 & 0.2 & 0.29 & 0.01 \\
\hline DA & 23 & 4.6 & 1.0 & 90.4 & 4.8 & 99.6 & 0.4 & 0.4 & 0.4 & 1.3 & 0.9 & 1.3 & 0.9 & 69.1 & 6. & 2.0 & 0.7 & 2.6 & 0.3 & 0.24 & 0.03 \\
\hline WP & 28 & 9.1 & I.I & 78.7 & 4.3 & 99.0 & 0.5 & 1.0 & 0.5 & 44.9 & 6.0 & 1.7 & 0.9 & 52.9 & 5.8 & 9.5 & 5.6 & 2.9 & 0.4 & 0.26 & 0.02 \\
\hline FM & 24 & 7.5 & 1.0 & 94.5 & 2.2 & 99.4 & 0.3 & 0.3 & 0.2 & 44.4 & 7.3 & 0.2 & 0.2 & 37.4 & 4.8 & 11.5 & 6.4 & 3.1 & 0.2 & 0.28 & 0.03 \\
\hline $\mathrm{FMu}$ & 23 & 8.6 & 0.6 & 80.5 & 7.0 & 97.6 & 0.7 & 1.8 & 0.7 & 38.0 & 6.3 & 0.0 & 0.0 & 50.7 & 6.2 & 8.3 & 4.6 & 3.4 & 0.2 & 0.27 & 0.02 \\
\hline $\mathrm{FP}$ & 42 & 11.9 & 1.1 & 83.1 & 3.7 & 97.8 & 0.9 & 1.9 & 0.9 & 28.5 & 3.8 & 0.9 & 0.5 & 54.0 & 2.7 & 10.5 & 3.8 & 4.2 & 0.2 & 0.31 & 0.01 \\
\hline $\mathrm{PO}$ & 30 & 13.6 & 0.8 & 65.3 & 3.4 & 100 & 0.0 & 0.0 & 0.0 & 22.1 & 4.8 & 2.3 & 0.3 & 72.6 & 4.8 & 4.7 & 2.5 & 3.5 & 0.2 & 0.20 & 0.03 \\
\hline PI & 16 & 4.9 & 1.0 & 9.7 & 2.9 & 99.6 & 0.2 & 0.4 & 0.2 & 90.6 & 2.9 & 3.3 & 0.9 & 6.0 & 2.2 & 17.1 & 8.3 & 2.9 & 0.4 & 0.09 & 0.02 \\
\hline PC & & 3.6 & 0.8 & 12.6 & 2.1 & 93.0 & 1.4 & 6.8 & 1.3 & 83.7 & 3.6 & 0.0 & 0.0 & 16.1 & 3.5 & 15.9 & 8.9 & 2.6 & 0.2 & 0.14 & 0.02 \\
\hline$\overline{\mathrm{x}}$ & 33.0 & 9.8 & & 74.1 & & 98.1 & & 1.3 & & 28.5 & & 1.9 & & 58.1 & & 7.2 & & 3.1 & & 0.21 & \\
\hline SE & 4.2 & I.I & & 2.7 & & 0.3 & & 0.3 & & 2.8 & & 0.4 & & 2.5 & & 1.5 & & 0.13 & & 0.02 & \\
\hline
\end{tabular}

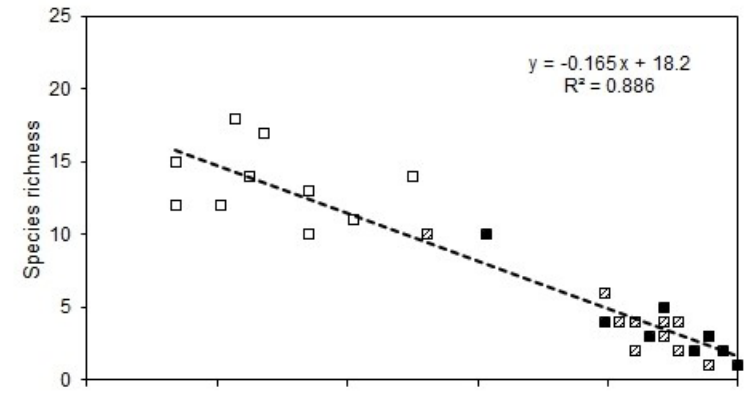

aOpen stand $\quad$ - Closed stand

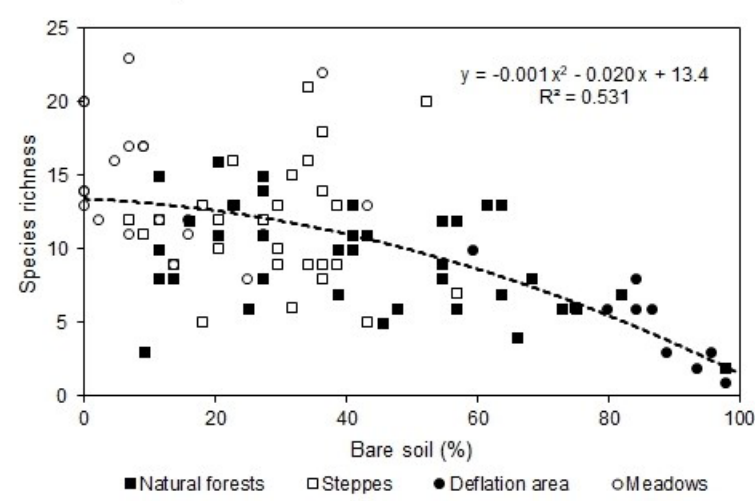

FIGURE 6 Bare soil and plant richness in the P. ponderosa stands (left) and natural vegetation units (right) of Aguas Frías and Litrán. The parameters of the regression function and the coefficient of determination $\left(R^{2}\right)$ are indicated (ANOVA, $\mathrm{p}<0.05$ ).

\section{PLANT FEATURES}

The vast majority of plants in all units were native (94.2\% of total species), whereas $\mathrm{MH}$ had the largest number of exotic species (7). Mean frequency of native species varied from $9.7 \%(P C)$ to $98.5 \%(M X)$, values which differed statistically between units (Tables I and $3)$. In pine stands the frequency of native plants was significantly higher in $\mathrm{PO}(65.3 \%)$ than in $\mathrm{PI}(12.6 \%)$ and PC (9.7\%) (LSD test, $F=119.6, p<0.001$ ) (Tables I and 3). Mean frequency of native species did not differ between fenced and unfenced conditions; FM $=94.5 \%$ and $\mathrm{FM}_{\mathrm{u}}=80.5 \%$, whereas $\mathrm{SH}=90.6 \%$ and $\mathrm{SH}_{u}=97.2 \%(t$ test, $\mathrm{p} \geq 0.05$ ) (Table 3). Mean frequency of perennial species varied from $92.9 \%$ (SE $=1.6)$ in $\mathrm{MH}$ to $100 \%$ in $\mathrm{PO}$ and $\mathrm{MX}$; these values differed statistically between units (Tables $I$ and 3 ). Mean frequency of perennial species within the mixed forest and high steppe did not differ between fenced and unfenced conditions ( $t$ test, $p \geq 0.05$ ). Mean frequency of herbaceous species ranged from $6.0 \%$ in PO to $94.2 \%$ in SL; these values differed statistically between units (Tables $\mathrm{I}$ and 3 ). Within pine stands, herbs were less frequent in $\mathrm{PC}(6.0 \%)$ and $\mathrm{PI}(16.1 \%)$ than PO (72.6\%) (LSD test, $F=96.9, p<0.00 I)$. Herb frequency did not differ between fenced and unfenced conditions within the mixed forest or high steppe; for example, $\mathrm{FM}=37.4 \%$, and $\mathrm{FM}_{\mathrm{u}}=50.7 \%$ (ANOVA, $\mathrm{F}$ $=2.86, \mathrm{p}=0.108)($ Table 3).

Life forms and biological spectra

Plants were classified as hemicryptophytes (63.1\% of total species), chamaephytes (I4.9\%), geophytes (7.1\%), nanophanerophytes (6.5\%), therophytes (5.8\%) and mesophanerophytes (2.6\%). FBS differed statistically between units from that expected under a random distribution of frequencies ( $X^{2}$ test, $\mathrm{p}<0.05, \mathrm{n}=6$ ). Although hemicryptophytes tended to dominate overall $(62.1 \%, \mathrm{SE}=1.9)$, FBS differed significantly between 

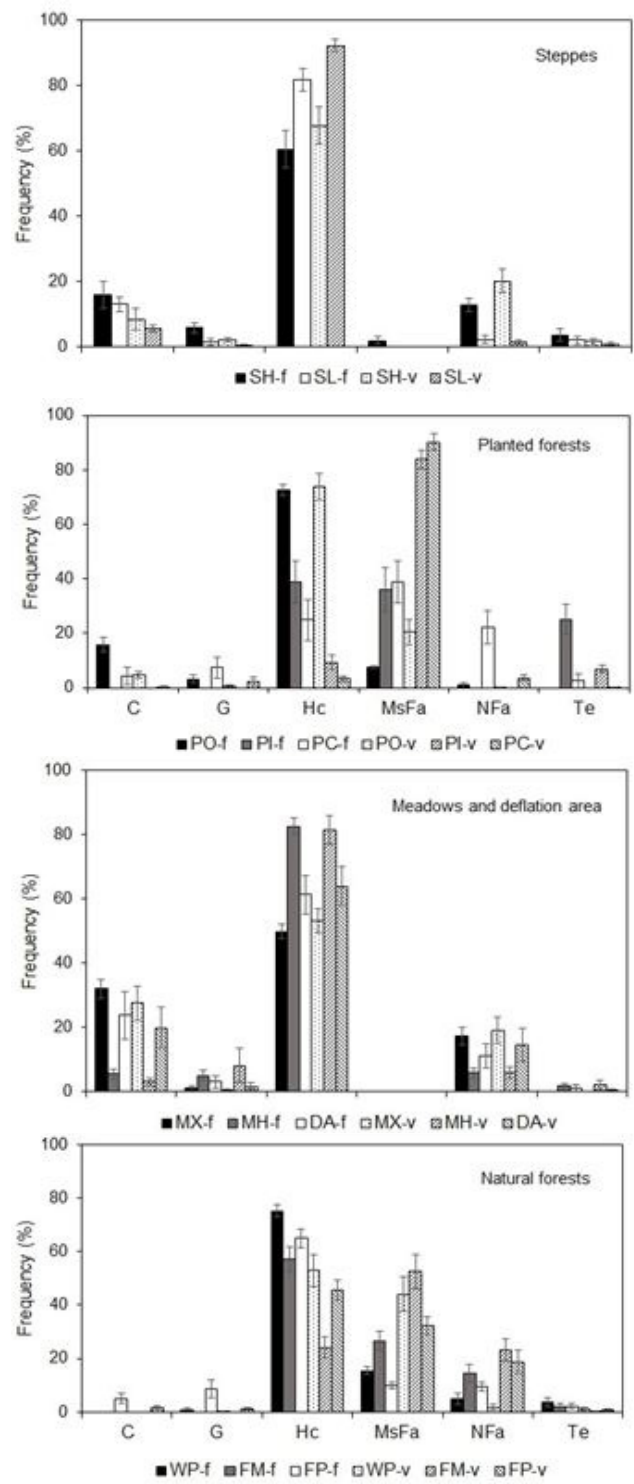

FIGURE 7 Floristic (f) and vegetational spectrum (v) of the vegetation units of Aguas Frías and Litrán. Vertical bars indicate the standard error of the mean ( $\mathrm{n}=10$ ). C: chamaephytes, G: geophytes, Hc: hemicryptophytes, MsFa: mesophanerophytes, NFa: nanophanerophytes, and Te: therophytes. $\mathrm{SH}$ : high herbaceous-shrubby steppe, SL: low herbaceousshrubby steppe, $M H$ : hygrophilous meadow, $M X$ : xerophilous meadow, DA: deflation area, WP: $A$. araucana woodland, FM: N. pumilio and A. araucana forest, FP: $N$. pumilio forest, PO: P. ponderosa open forest, PI: $P$. ponderosa intermediate forest and PC: $P$. ponderosa closed forest.

units, judging from differences in the frequency of this life form (Table I, Figure 7). Hemicryptophyte frequency ranged from $24.8 \%$ in $\mathrm{PC}$ (SE $=7.6$ ) to $82.6 \%$ in $\mathrm{MH}$ $(\mathrm{SE}=2.7)$, whereas mesophanerophytes formed the largest class in PC (38.8\%, SE = 7.8). Hemicryptophyte frequency did not differ between FM (57.1\%, SE = 4.4) and $\mathrm{FM}_{u}(60.9 \%, \mathrm{SE}=3.4)(t$ test, $\mathrm{p}=0.499)$, whereas frequency in $\mathrm{SH}(60.5 \%, \mathrm{SE}=5.8)$ was lower than in $\mathrm{SH}_{u}(77.3 \%, \mathrm{SE}=2.8)(t$ test, $\mathrm{p}=0.017)(\mathrm{n}$ $=10)$. In pine stands, hemicryptophytes increased significantly as CC decreased (ANOVA, F $=16.40, p<$ $0.001, \mathrm{n}=10$ ); in $\mathrm{PC}, \mathrm{PI}$ and $\mathrm{PO}$ frequency was $24.8 \%$ (SE $=7.6$ ), 38.8\% (SE $=7.9)$ and $72.6 \%$ (SE $=2.1$ ), respectively (LSD test, $\mathrm{p}<0.05, \mathrm{n}=10$ ). Hemicryptophyte frequency was similar in $\mathrm{PO}$ and steppe units $(\mathrm{SH}, 60.5 \%, \mathrm{SE}=5.8 ; \mathrm{SL}, 81.7 \%$, SE = 3.5). Geophytes constituted the least frequent life form, ranging from $0 \%(\mathrm{PI}$ and $\mathrm{FM}$ ) to $8.6 \%$ (FP) (Figure 7).

VBS differed statistically from that expected under a random distribution of life forms ( $X^{2}$ test, $\left.p<0.05, n=6\right)$. It was dominated by hemicryptophytes $(52.7 \%, \mathrm{SE}=2.6)$, with therophytes $(1.2 \%, S E=0.2)$ and geophytes $(1.3 \%$, $\mathrm{SE}=0.2$ ) constituting the least frequent life forms. This spectrum differed between units, judging from differences in hemicryptophyte frequency; maximum frequencies were recorded in SL (92.2\%, SE = 1.9), SH (81.4\%, SE $=4.5)$ and $\mathrm{MH}(8 \mathrm{I} .3 \%, \mathrm{SE}=4.5)$, while the minimum value was found in PC (3.3\%, SE = I.I) (Table I, Figure 7). Hemicryptophyte frequency differed between FM (24.1\%, $\mathrm{SE}=3.9)$ and $\mathrm{FM}_{u}(42.0 \%, \mathrm{SE}=7.2)(t$ test, $\mathrm{p}=0.042)$, but not between $\mathrm{SH}(67.7$ is $=5.7)$ and $\mathrm{SH}_{u}(76.2 \%$, $\mathrm{SE}=1.7)(t$ test, $\mathrm{p}=0.169)(\mathrm{n}=10)$. In pine stands, hemicryptophyte frequency increased significantly as CC decreased: PC, 3.3\% (SE = I.I); PI, 9.3\% (SE = 2.7); PO, $74.0 \%(\mathrm{SE}=4.9)(\mathrm{LSD}$ test, $\mathrm{F}=141.40, \mathrm{p}<0.001, \mathrm{n}=$ 10). Frequency in $\mathrm{PO}$ resembled that in $\mathrm{SH}(67.7 \%$, SE $=5.7)$. In tree-dominated units, mean mesophanerophyte frequency ranged from $20.4 \%(B A, S E=4.8)$ to $90.2 \%$ $(P C, S E=3.0)$ (Figure 7). Hemicryptophyte frequency was very low in PC $(3.3 \%)$, and increased in $\mathrm{PO}(74.0 \%)$ to resemble values from the steppe (SH, 67.7\%; SL, 92.3\%). The difference between FBS and VBS ranged from $1.2 \%$ in $\mathrm{MH}$ to $17.1 \%$ in PC; differences larger than $5 \%$ were found only in FM, FP, PI and PC (Table 3). Hemicryptophyte frequency differed significantly between the spectra only in forest units (Kolmogórov-Smirnov test, $p<0.05$ ).

\section{Life form diversity}

LFR ranged from 2.6 (PC, DA, SL) to 4.2 (FP), values differing statistically between units. Although LFR was greater in $\mathrm{PO}$ (3.5) than in PC, these differences were not significant (ANOVA, $P=0.075, F=2.86$ ). LFR did not differ between FM (3.I) and $\mathrm{FM}_{u}$ (3.4) $(t$ test, $\mathrm{p}=0.232$ ), but did vary between $\mathrm{SH}(3.7)$ and $\mathrm{SH}_{u}$ (2.8) ( $t$ test, $\mathrm{p}=0.023)(\mathrm{n}=10)$ (Tables I and 3). LFD was lowest in SL (0.08) and PC (0.09) and highest in FP $(0.3 \mathrm{I})$; these values differed statistically between units. In pine stands, LFD tended to increase significantly as cover decreased: PC, 0.09; PI, 0.14 and PO, 0.20 (LSD test, $\mathrm{p}$ 
$=0.023)$. LFD in FM (0.28) and $\mathrm{FM}_{\mathrm{u}}(0.27)$ were similar (ANOVA, $\mathrm{p}=0.828, \mathrm{~F}=0.05)$ and LFD in $\mathrm{SH}(0.23)$ and $\mathrm{SH}_{\mathrm{u}}(0.2 \mathrm{I})$ were similar (ANOVA, $\mathrm{p}=0.399, \mathrm{~F}=$ 0.74) (Tables I and 3). Within plantations, LFD was large in $\mathrm{PI}$ with 30 to $60 \%$ of $B S$, but decreased in $\mathrm{PO}$ and $\mathrm{PC}$, which exhibited $B S$ apart from this range (ANOVA, $\mathrm{p}<$ $0.001, \mathrm{n}=30$ ) (Figure 8).
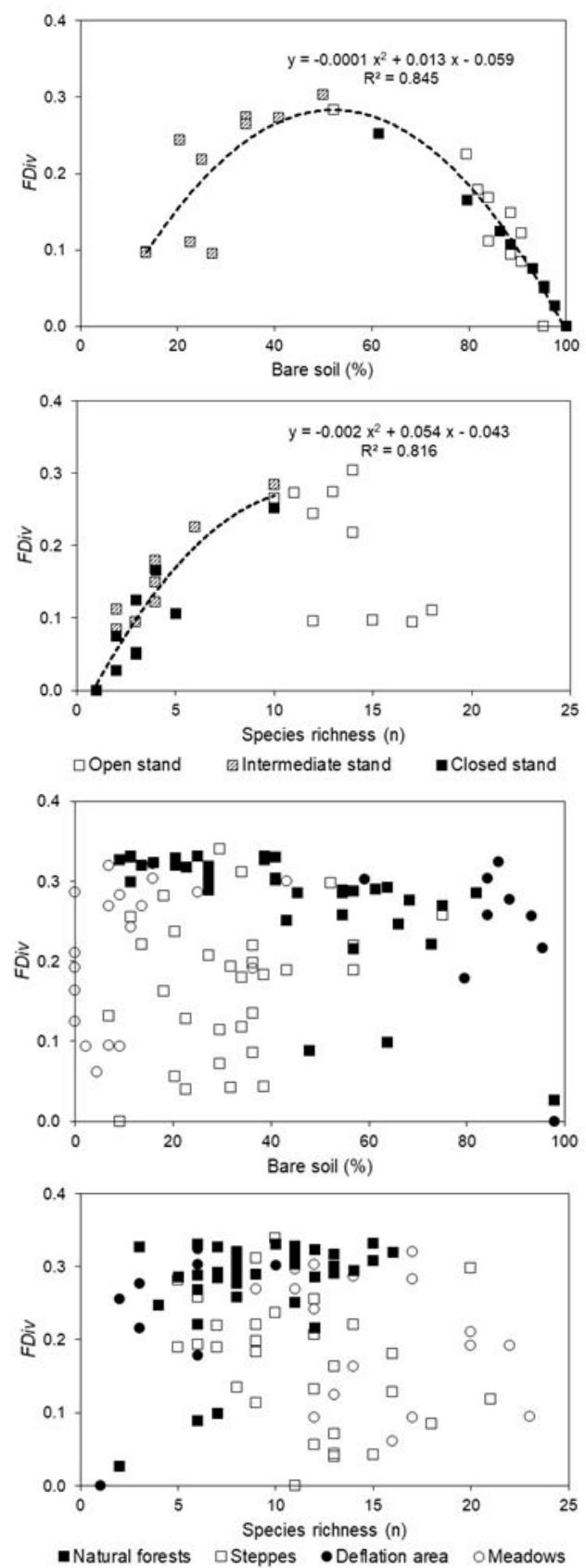

FIGURE 8 Bare soil, species richness and life form diversity (FDiv) in the $P$. ponderosa stands (left) and natural vegetation units (right) of Aguas Frías and Litrán. The parameters of the regression function and the coefficient of determination $\left(R^{2}\right)$ are indicated when slope is statistically different from 0 (ANOVA, $p<0.05$ ).
Units covered by natural vegetation showed no significant relationship between $B S$ and $L F D$, either when the entire database was analysed together or when separated in units (ANOVA, $p \geq 0.05, n=$ 100) (Figure 8). In PC and PI, LFD tended to increase asymptotically as $S_{t}$ increased (ANOVA, $\mathrm{p}<0.00 \mathrm{I}, \mathrm{n}=$ 20). In contrast, $P O$ and units covered by natural vegetation showed no significant statistical relationship between these variables, either when the entire database was analysed together or when separated into different units (ANOVA, $p \geq 0.05$ ) (Figure 8). There was no bi-dimensional relationship between LFR and LFD (ANOVA, $\mathrm{F}=3.78$, $\mathrm{p}$ $=0.078, \mathrm{n}=13$ ). Multiple regression (stepwise, forward selection method) among LFD, BS and $S_{t}$ for PO, PI and PC produced the function $L F D=0.00072 B S+0.0131 S_{t}$ (MANOVA, $p<0.00 I, R^{2}=0.803, n=30$ ), whereas for the remaining units the function was $L F D=0.00228 B S+$ $0.0123 S_{t}$ (MANOVA, $\mathrm{p}<0.00 \mathrm{I}, \mathrm{R}^{2}=0.793, \mathrm{n}=100$ ). Goodness of fit between observed and modelled values was very low for the entire data set (MANOVA, $p=0.005$, $R^{2}=0.061, n=130$ ).

\section{DISCUSSION}

The effect of plantations on species richness was evaluated in regional studies. Bremer and Farley (2010) found a decrease in the richness of native species in plantations compared to pastures, shrublands, and primary forests. However, richness increased when reference communities were secondary forests, degraded grasslands and deforested grazing areas. In the Argentinean Patagonia, dense plantations of Pinus exhibited lower diversity of plants (Paritsis and Aysen, 2008), insects (Corley et al., 2006), birds (Lantschner et al., 2008) and mammals (Lantschner et al., 20II, 20I2), compared to the surrounding natural forest, grassland, and open plantations. Animal diversity tended to correlate positively with understory complexity and landscape heterogeneity, and negatively with stand cover (Paritsis and Aysen, 2008; Lantschner et al., 20II, 20I2). In structurally simple Pinus radiata stands from Chile, depletion of diversity was documented in reptiles (Uribe and Estadés, 20I4), birds (Tomasevic and Estadés, 2008; Vergara and Armesto, 2009; Najera and Simonetti, 2010), and terrestrial and flying mammals (Ramirez and Simonetti, 20II; Rodríguez-San Pedro and Simonetti, 20I3; Meynard et al., 20I4). Stratified undergrowth within $P$. radiata stands provided habitat for medium-sized mammals and natural regeneration of the original vegetation (Guerrero and Bustamante, 2007; Simonetti et al., 20I3). 
PAR on the floor of the closed stand (2\%) was probably low because of high reflection and absorption of light caused by extensive canopy cover ( $91 \%$ ) (Canham et al., 1990). A well-developed canopy would also imply higher rates of evapotranspiration, and interception and consumption of water (Weigandt et al., 2015), which would explain the reduced soil water content measured during the dry season (9.6\%). However, a denser stand structure can also promote lower air temperatures, reducing evaporation and partly compensating for water losses through the canopy (Canham et al., 1990; Geiger et al., 2003). A decrease in canopy cover caused an increase in luminosity on the forest floor, and probably in soil water content, to attain levels similar to the steppe. The open stand showed $29 \%$ canopy cover, $42 \%$ light intensity, and $20 \%$ soil moisture, whereas in the high and low steppe soil moisture was $29 \%$ and $18 \%$, respectively. In the closed stand, lower values of light intensity and soil moisture, given a large canopy cover, would have promoted large amounts of bare soil (89\%); in the open stand, soil cover decreased to $28 \%$, resembling the values found for the high $(27 \%)$ and low steppe (28\%). Low richness of understory plants in the closed stand (3.6) was probably related to the restricted possibility of establishment in an environment with a shortage of essential aerial and underground resources. However, species richness in the open stand (13.6) and in the low steppe (14.8) was similar.

Although the high frequency of exotic species in the closed stand $(90 \%)$ was associated with the exotic $P$. ponderosa, the amount of this plant type was very low on the whole $(2 / 16)$ and comparable with that of other units (e.g. high steppe, 4/47 and low steppe, 4/38). A pine stand would not provide a particularly advantageous habitat for exotic herbs and shrubs, reducing the possibility of biological invasion. The conversion of steppe to forest, and the resulting increase in tree canopy cover, was linked to the severe decline in hemicryptophytes and herbs. Hemicryptophytes were dominant within the floristic spectrum in all natural units, reflecting plant adaptation to cold winters and dry summers (Bertolami et al., 2008). Chamaephytes attained relevance in the xerophilous meadow, as in other southern rocky outcrops, a phenomenon also interpreted to be a consequence of the harsh climate (Speziale and Ezcurra, 20/2). Evergreen and deciduous mesophanerophytes, namely tall perennials with buds emerging from aerial parts, were dominant at the mid elevation of south and east facing slopes, indicating a more humid environment.
Nanophanerophytes, which are low-height phanerophytes, increased their participation in the understory of pine stands as cover developed, reflecting the role of a closed canopy in microclimate amelioration. Within the closed stand, mesophanerophyte dominance, higher values for canopy cover and bare ground, and a small number of species in the understory led to low taxonomic and life form diversity, which increased significantly in the intermediate and open stands to resemble values of the high steppe. The attenuation of light and precipitation on the forest floor is likely to act as an environmental filter, restricting the pool of viable habits and reducing community diversity (Kleidon et al., 2009). The xerophilous meadow was one of the most diverse habitats in terms of life forms. It comprised around I/3 of total plant species and a large number of families in an extremely restricted area, which barely exceeded 1\% of Aguas Frías. The vast majority of plants were native species not found in the matrix, as only $42 \%$ were commonly found in the steppe, $30 \%$ in natural forest, and $18 \%$ in the closed stand. This unit also presented high life form diversity, equivalent to that of the natural forests and 3.2 times higher than the closed stand. These rocky outcrops have higher temperature, insolation and wind frequency and intensity, plus lower air humidity, water and nutrient content than the surrounding ecosystems (Szarzynski, 2000). This setting, together with a variety of microhabitats such as cracks and overhangs, and lower fire and grazing pressure, enhances "specialist" diversity (Milchunas and Noy-Meir, 2002; Galende and Raffaele, 20I3). It probably also represents refuges of cold-adapted glacial relict paleofloras (Speziale and Ezcurra, 20I2).

The hygrophilous meadow of Aguas Frias had a high number (10\%) and frequency (18\%), of exotic plant species, low life form diversity $(0.15)$ and the largest number of plant families (23) and species (68). This richness was 4.3 and I.6 times that of the closed stand and the pure forest, respectively. Wetlands in northwestern Patagonia are very productive and biodiverse ecosystems mainly threatened by overgrazing, which causes an increase in bare soil, gully formation and drainage, and the risk of plant invasion (Chimner et al., 20II). There is also concern about the potential effect replacing grassland with plantation may have on water recharge (Weigandt et al., 20I5). The deflation area is an intense human-degraded unit, which shows a large proportion of unvegetated soil and reduced taxonomic and life form richness (Frugoni et al., 2016).

The fenced steppe of Aguas Frías showed a significantly lower amount of bare soil $(27 \%)$ and higher taxonomic (47 species) and life form richness (3.7) than 
the unfenced steppe ( $40 \%, 24$ species, 2.8 , respectively). Grace and Jutila (1999) found that reduction in the species pool of grazed areas was predominantly caused by selective herbivory. Grime (2006) hypothesized that the decline in richness is because herbivory reduces competition, although herbivory can intensify the effects of competition. Besides, such generalization ignores the evolutionary relation between plants and grazers (Milchunas and Noy-Meir, 2002). In the mixed forest, the amount of bare soil was lower in the fenced than in the unfenced condition (34\% and $51 \%$, respectively). In Patagonia, the enclosing of forest stations protects young trees against the herbivory of livestock and native and introduced wildlife. However, this practice also confers significant ecological benefits on the surrounding natural and semi-natural environments, which usually exhibit substantial degradation due to fire and overgrazing (Frugoni et al., 2016).

\section{CONCLUSIONS}

In Aguas Frías, ecological indicators improved after seven years of project implementation. In Litrán, dense stands of $P$. ponderosa negatively affected soil cover, plant richness, and life form diversity. These variables came close to the values of the steppe of reference as canopy cover decreased. Projects for the production of goods and services crucial for the biota and people, demand functional ecosystems over time and space. Greater compatibility between harbouring a wide variety of wild

List of abbreviations used in the text.

\begin{tabular}{|c|c|}
\hline Initial & Meaning \\
\hline BA & Basal area \\
\hline BS & Bare soil \\
\hline $\mathrm{CC}$ & Crown cover \\
\hline $\mathrm{D}$ & Tree density \\
\hline$d$ & Distance between trees \\
\hline DA & Deflation area \\
\hline $\mathrm{db}$ & Diameter at base height \\
\hline FBS & Floristic biological spectrum \\
\hline FM & Nothofagus pumilio and Araucaria araucana fenced forest \\
\hline $\mathrm{FMu}$ & Nothofagus pumilio and Araucaria araucana unfenced forest \\
\hline FP & Nothofagus pumilio forest \\
\hline $\mathrm{h}$ & Tree height \\
\hline 15 & Length of the five internodes above $1.3 \mathrm{~m}$ \\
\hline LFD & Life form diversity \\
\hline LFR & Life form richness \\
\hline $\mathrm{MH}$ & Hygrophilous meadow \\
\hline MX & Xerophilous meadow \\
\hline PAR & Photosynthetically active radiation \\
\hline PC & Pinus ponderosa closed forest \\
\hline $\mathrm{PI}$ & Pinus ponderosa intermediate forest \\
\hline $\mathrm{PO}$ & Pinus ponderosa open forest \\
\hline$\hat{S}$ & Mean species richness \\
\hline SBD & Soil bulk density \\
\hline $\mathrm{SH}$ & High herbaceous-shrubby fenced steppe \\
\hline $\mathrm{SHu}$ & High herbaceous-shrubby unfenced steppe \\
\hline $\mathrm{SI} 20$ & Site index at $20 \mathrm{yr}$ \\
\hline SL & Low herbaceous-shrubby steppe \\
\hline SM & Soil moisture \\
\hline St & Total species richness \\
\hline VBS & Vegetational biological spectrum \\
\hline WP & Araucana araucana woodland \\
\hline
\end{tabular}

species and timber production in this anthropogenic habitat requires, as a priority, the maintenance of fencing and reduced tree spacing. Although such a project may represent a decline in productivity, the resulting enhanced ecosystem and aesthetic value will increase opportunities for further economic support from society.

\section{ACKNOWLEDGEMENTS}

This study was funded by Universidad Nacional del Comahue and Unidad de Cambio Rural (Ministerio de Agricultura, Ganadería y Pesca). Yacimientos Petrolíferos Fiscales and Corporación Forestal Neuquina allowed to collect data in the study area.

\section{REFERENCES}

AIC. Temperatura y Precipitación Mensual. Autoridad Interjurisdiccional de las Cuencas de los Ríos Limay, Neuquén y Negro, 2015. 56 p.

ANDENMATTEN, E.; LETOURNEAU, F. Predicción y proyección del rendimiento de pino ponderosa en las provincias de Chubut y Río Negro, Argentina. Quebracho, v. 10, p. I4-25, 2003.

BATALHA, M. A.; MARTINS, F. R. Floristic, frequency, and vegetation life-form spectra of a cerrado site. Brazilian Journal of Biology, v. 64, p. 203-209, 2004.

BERTOLAMI, M. A.; RUETER, B. L.; BENÍTEZ, M. Análisis de espectros biológicos ponderados en pampas del sudeste de la provincia de Chubut. Multequina, v. 17, p. 93-107, 2008.

BREMER, L.; FARLEY, K. Does plantation forestry restore biodiversity or create green deserts? A synthesis of the effects of land-use transitions on plant species richness. Biodiversity Conservation, v. 19, p. 3893-3915, 2010.

CADOTTE, M. W.; CARSCADDEN, K.; MIROTCHNICK, N. Beyond species: functional diversity and the maintenance of ecological processes and services. Journal of Applied Ecology, v. 48, p. 1079-1087, 201 I.

CANHAM, C. D.; DENSLOW, J. S.; PLATT, W. J.; RUNKLE, J. R.; SPIES, T. A.; WHITE, P. S. Light regimes beneath closed canopies and tree-fall gaps in temperate and tropical forests. Canadian Journal of Forest Research, v. 20, p. $620-631,1990$.

CARNUS, J.-M.; PARROTTA, J.; BROCKERHOFF, E.; ARBEZ, M.; JACTEL, H.; KREMER, A.; LAMB, D.; O'HARA, K.; WALTERS, B. Planted forests and biodiversity. Journal of Forestry, v. 104 p. 65-77, 2006.

CBD. Strategic plan for biodiversity 20 I I-2020 and the Aichi targets. Secretariat of the Convention on Biological Diversity. Available via DIALOG. Available at: http://www. cbd.int/doc/strategic-plan/20 I I-2020/Aichi-TargetsN.pdf. Accessed in: April 30th 2019. 
CFI. Inventario del bosque implantado de la provincia de Neuquén. Consejo Federal de Inversiones, 2009. 65 p.

CHIMNER, R. A.; BONVISSUTO, G. L.; CREMONA, M. V.; GAITÁN, J. J.; LÓPEZ, C. R. Ecohydrological conditions of wetlands along a precipitation gradient in Patagonia, Argentina. Ecología Austral, v. 2 I, p. 329-337, 201 I.

CHOWN, S. L.; MCGEOCH, M. A. Measuring biodiversity in managed landscapes. In: MAGURRAN, A. E.; MCGILL, B. J. Biological diversity: frontiers in measurement and assessment. Oxford University Press, 20I I. p. 252-264.

CORLEY, J.; SACKMANN, P.; RUSCH, V.; BETTINELLI, J.; PARITSIS, J. Effects of pine silviculture on the ant assemblages (Hymenoptera: Formicidae) of the Patagonian steppe. Forest Ecology and Management, v. 222, p. I62-I66, 2006.

DEVICTOR, V.; MOUILLOT, D.; MEYNARD, C.; JIGUET, F; THUILLER, W.; MOUQUET, N. Spatial mismatch and congruence between taxonomic, phylogenetic and functional diversity: the need for integrative conservation strategies in a changing world. Ecology Letters, v. I3, 1030-1040, 2010.

DRAKARE, S.; LENNON, J. J.; HILLEBRAND, H. The imprint of the geographical, evolutionary and ecological context on speciesarea relationships. Ecology Letters v. 9 p. 215-227, 2006.

FAO. The State of the World's Forests: Forest Pathways to Sustainable Development. Food and Agriculture Organization, 2018. $118 \mathrm{p}$.

FRUGONI, M. C.; DEZZOTTI, A.; MEDINA, A.; SBRANCIA R.; MORTORO, A. Design and evaluation of an afforestation project based on geopedologic and ecological information in north-western Patagonia, Argentina. In: ZINCK, A.; METTERNICHT, G.; BOCCO, G.; DEL VALLE, H. Geopedology: an integration of geomorphology and pedology for soil and landscape studies. Springer, 2016. p. 480-504.

GALENDE, G. I.; RAFFAELE, E. Feeding behavior of herbivores in rocky outcrops of northwestern Patagonia and its importance in conservation. Advances in Zoology Research, v. 5, p. I53-157, 2013.

GEIGER, R.; ARON, R. H.; TODHUNTER, P. The Climate near the Ground. Rowman and Littlefield Publishers, 2003. 584 p.

GRACE, J. B.; JUTILA, H. The relationship between species density and community biomass in grazed and ungrazed coastal meadows. Oikos, v. 85, p. 398-408, 1999.

GRIME, J. P. Plant Strategies, Vegetation Processes, and Ecosystem Properties. Wiley, 2006. 456 p.

GUERRERO, P. C.; BUSTAMANTE, R. O. Can native tree species regenerate in Pinus radiata plantations in Chile? Evidence from field and laboratory experiments. Forest Ecology and Management, v. 253, p. 97-102, 2007.
HAINES-YOUNG, R. Land use and biodiversity relationships. Land Use Policy, v. 26, p. I78-186, 2009.

IBD. Flora del conosur. Instituto de Botánica Darwinion. Available at: http://www2.darwin. edu.ar. Accessed in: March I0th 2019

KENT, M. Vegetation Description and Data Analysis: A Practical Approach. Wiley-Blackwell, 20I I. 428 p.

KLEIDON, A.; ADAMS, J.; PAVLICK, R.; REU, B. Simulated geographic variations of plant species richness, evenness and abundance using climatic constraints on plant functional diversity. Environmental Research Letters, v. 4, p. I-5, 2009.

LACLAU, P.; ANDENMATTEN, E.; LETOURNEAU, F; LOGUERCIO, G. Carbon sequestration of ponderosa pine plantations in northwestern Patagonia. In: BRAVO, F.; LEMAY, V.; JANDL, R. Managing forest ecosystems: the challenge of climate change Springer, 2017. p. 329-349.

LALIBERTÉ, E.; LEGENDRE, P.; SHIPLEY, B. Package “FD”: measuring functional diversity (FD) from multiple traits, and other tools for functional ecology. Available at: http://www.elaliberte.info. Accessed in: April 5th 2019.

LANTSCHNER, M. V.; RUSCH, V.; PEYROU, C. Bird assemblages in pine plantations replacing native ecosystems in NW Patagonia. Biodiverity Conservation, v. 17, 969-989, 2008.

LANTSCHNER, M. V.; RUSCH, V.; HAYES, J. P. Influences of pine plantations on small mammal assemblages of the Patagonian forest-steppe ecotone. Mammalia, v. 75, p. 249-55, 2011.

LANTSCHNER, M. V.; RUSCH, V.; HAYES, J. P. Habitat use by carnivores at different spatial scales in a plantation forest landscape in Patagonia, Argentina. Forest Ecology and Management, v. 269, p. 27I-278, 2012.

LINDQUIST, E. J.; D'ANNUNZIO, R.; GERRAND, A.; MACDICKEN, K; ACHARD, F; STIBIG, H-J; EVA, H; BEUCHLE, R.; MAYAUX, P.; BRINK, A.; SAN-MIGUELAYANZ, J. Cambio de Uso de las Tierras Forestales Mundiales 1990-2005. Documento Forestal 169. Food and Agriculture Organization, 2013. 42 p.

LOGUERCIO, G.; GONDA, H.; JOVANOVSKI, A. Necesidades de manejo de los bosques plantados en las provincias de Neuquén, Rio Negro y Chubut. Revista Producción Forestal v. I, p. I3-17, 201।.

MAGyP. Argentina: Plantaciones Forestales y Gestión Sostenible. Unidad de Cambio Rural. Ministerio de Agricultura, Ganadería y Pesca, Buenos Aires, 20I4. I5 p.

MEYNARD, C. N.; SOTO-GAMBOA, M.; HEADY III, P. A.; FRICK, W. F. Bats of the Chilean temperate rainforest: patterns of landscape use in a mosaic of native forests, eucalyptus plantations and grasslands within a South American biodiversity hotspot. Biodiversity Conservation, v. 23, p. 1949-1963, 2014. 
MILCHUNAS, D. G.; NOY-MEIR, I. Grazing refuges, external avoidance of herbivory and plant diversity. Oikos, v. 99, p. II3-|30, 2002.

MOTTUS, M; SULEV, M.; BARET, F;; LOPEZ-LOZANO, R.; REINART, A. Photosynthetically active radiation: measurement and modeling. In: MEYERS, R. Encyclopedia of sustainability science and technology. Springer, 201 I. p. $7970-8000$

NAJERA, A.; SIMONETTI, J. A. Enhancing avifauna in commercial plantations. Conservation Biology, v. 24, p. 319-324, 2010.

OVERBEEK, W.; KRÖGER, M.; GERBER, J. An Overview of Industrial Tree Plantation Conflicts in the Global South: Conflicts, Trends, and Resistance Struggles. Environmental Justice Organisations, Liabilities and Trade, 20I2. 100 p.

OYARZÁBAL, M.; CLAVIJO, J.; OAKLEY, L; BIGANZOLI, F; TOGNETTI, P.; BARBERIS, I.; MATURO, H.; ARAGON, R.; CAMPANELLO, P.; PRADO, D.; OESTERHELD, M.; LEÓN, R. Unidades de vegetación de la Argentina. Ecología Austral, v. 28, p. 40-63, 2018.

PARITSIS, J.; AIZEN M. Effects of exotic conifer plantations on the biodiversity of understory plants, epigeal beetles and birds in Nothofagus dombeyi forests. Forest Ecology and Management, v. 255, p. I575-I 583, 2008.

PEEL, M. C.; FINLAYSON, B. L.; MCMAHON, T. A. Updated world map of the Köppen-Geiger climate classification. Hydrology and Earth System Sciences, v. I I, p. I633-I644, 2007.

RAMÍREZ, P. A.; SIMONETTI, J. A. Conservation opportunities in commercial plantations: the case of mammals. Journal of Nature Conservation, v. 19, v. 35 I-355, 20 I I.

RAUNKI/ER, C. The Life Forms of Plants and Statistical Plant Geography. Oxford University Press, 1934. 632 p.

RODRÍGUEZ-SAN PEDRO, A.; SIMONETTI, J. A. Foraging activity by bats in a fragmented landscape dominated by exotic pine plantations in central Chile. Acta Chiropterologica, v. I5, p. 393-398, 2013.

SAMLA. Sistema de Apoyo Metodológico para Laboratorio de Análisis de Suelos y Aguas, Vegetales y Enmiendas Orgánicas. Secretaría de Agricultura, Ganadería, Pesca, Alimentos y Forestación, Buenos Aires, 2004. Versión electrónica.

SIMBERLOFF, D.; NÚÑEZ, M.; LEDGARD N.; PAUCHARD, A.; RICHARDSON, D.; SARASOLA, M.; VAN WILGEN, B.; ZALBA, S.; ZENNI, R.; BUSTAMANTE, R.; PEÑA, E.; ZILLER, S. Spread and impact of introduced conifers in South America: lessons from other southern hemisphere regions. Austral Ecology, v. 35, p. 489-504, 2010.
SIMONETTI, J. A.; GREZ, A.; ESTADÉS, C. Providing habitat for native mammals through understory enhancement in forestry plantations. Conservation Biology, v. 27, p. III7-II2I, 20I3.

SPEZIALE, K. L.; EZCURRA, C. The role of outcrops in the diversity of Patagonian vegetation: relicts of glacial palaeofloras? Flora, v. 207, p. I4I-149, 2012.

SZARZYNSKI, J. Xeric islands: environmental conditions on inselbergs. In: POREMBSKI, S.; BARTHLOTT, W. Inselbergs: biotic diversity of isolated rock outcrops in tropical and temperate regions. Springer, 2000. p. 37-48.

TILMAN, D. Functional diversity. In: LEVIN, S. A. Encyclopaedia of biodiversity. Academic Press, $200 \mathrm{I}$. p. $109-120$.

TOMASEVIC, J. A.; ESTADÉS, C. F. Effects of the structure of pine plantations on their "softness" as barriers for ground-dwelling forest birds in south-central Chile. Forest Ecology and Management, v. 255, p. 810-816, 2008.

URIBE, S. V.; ESTADÉS, C. F. Reptiles in Monterey pine plantations of the Coastal Range of Central Chile. Revista Chilena de Historia Natural, v. 87, p. 2532, 2014

VERGARA, P. M.; ARMESTO, J. J. Responses of Chilean forest birds to anthropogenic habitat fragmentation across spatial scales. Landscape Ecology, v. 24, p. 25-38, 2009.

VILLÉGER, S.; MASON, N. W.; MOUILLOT, D. New multidimensional functional diversity indices for a multifaceted framework in functional ecology. Ecology, v. 89, p. 2290-230I, 2008.

WEIGANDT, M.; GYENGE, J.; FERNÁNDEZ, M. E.; GYENGE, J.; SCHLICHTER, T. Afforestations and wetlands, are they a good combination? Study of water fluxes in two cases of Patagonian wetlands. Ecohydrology, v. 8, p. 4I6-425, 2014.

WEIHER, E. A primer of traits and functional diversity. In: MAGURRAN, A. E.; MCGILL, B. J. Biological diversity: frontiers in measurement and assessment. Oxford University Press, 201 I. p. I75-193. 